\title{
DISTRIBUSI SPASIAL MASYARAKAT TERKATEGORI MISKIN DALAM BASIS DATA TERPADU KABUPATEN SRAGEN
}

\author{
Muhammad Arif ${ }^{1}$, Sidiq Permono Nugroho ${ }^{2}$, Wawan Kurniawan ${ }^{3}$, Wahyudi ${ }^{4}$, \\ Agus Ulinuha ${ }^{5}$, Eni Purwandari ${ }^{6}$ \\ ${ }^{1,2,56}$ Universitas Muhammadiyah Surakarta \\ ${ }^{3,4}$ Badan Perencanaan Pembangunan Daerah, Penelitian dan Pengembangan Kabupaten Sragen \\ 1arif@ums.ac.id, ${ }^{2}$ sidik_nugroho78@yahoo.com, ${ }^{3}$ wankur45@gmail.com, \\ 4wahyudi1964@gmail.com, ${ }^{5}$ agus.ulinuha@ums.ac.id, ${ }^{6}$ eny.purwandari@ums.ac.id
}

\begin{abstract}
This study aims to provide graphic information based on spatial analysis of statistics on the distribution and concentration of poor people in Sragen Regency. The analysis in this study was carried out by calculating the concentration of poor community areas with Jenks Natural Break distribution method, then the results were combined with a spatial approach so that the concentration map of the poor in Sragen Regency was obtained. The results of the analysis in this study showed that the people with the lowest 40\% welfare condition were identified as 81,620 Heads of Households and as many as 250,294 individuals, then an increase of 30\% in the 2017 data update. These groups were mostly concentrated in the north and west Sragen Regency with a pattern that tends to cluster and is concentrated in Sumberlawang and Tanon Subdistricts, the number of poor people in this area is identified as 39\% of the proportion of its population. Spatially these two regions are directly adjacent, this indicates that the geographical element has an impact on the number of poor people in that regions.
\end{abstract}

Keyword: concentration of poor people, integrated database, Geographic Information System

Abstraksi. Kajian ini berupaya untuk memberikan informasi grafis berdasarkan analisis spasial statistic terhadap sebaran dan konsentrasi masyarakat miskin di Kabupaten Sragen. Dalam analisisnya kajian ini dilakuakan dengan menghitung konsentasi wilayah kelompok masyarat miskin dengan metode distribusi Natural Break Jenks, kemudian hasil tersebut dikombinasikan dengan pendeakatan spasial sehingga didapatkan peta konsentrasi masyarakat miskin di Kabupaten Sragen. Hasil analisis dalam kajian ini menunjukkan bahwa masyarakat dengan kondisi $40 \%$ kesejahteraan terendah di Sragen teridentifikasi sejumlah 81.620 Kepala Rumah Tangga dan sebanyak 250.294 individu, kemudian terjadi penambahan sebanyak $30 \%$ pada update data Tahun 2017. Kelompok masyarakat ini sebagian besar terkonsentrasi pada wilayah utara dan barat Kabupaten Sragen dengan pola yang cenderung mengelompok dan terkonsentrasi di wilayah Kecamatan Sumberlawang dan Kecamatan Tanon, jumlah masyarakat miskin pada daerah ini teridentifikasi sebanyak 39\% dari proporsi penduduknya. Secara spasial kedua wilayah ini berdekatan langsung, maka dapat diartikan bahwa unsur geografis memiliki impact terhadap banyaknya penduduk miskin pada kedua wilayah ini.

Keyword: konsentrasi penduduk miskin Sragen, basis data terpadu, Sistem Informasi Geografis.

\section{PENDAHULUAN}

Kabupaten Sragen sebagai daerah penyangga simpul ekonomi wilayah VIII Pulau Jawa, mempunyai peran penting dalam sirkulasi dan distribusi faktor-faktor ekonomi wilayah Propinsi Jawa Tengah. Secara geografis Sragen terletak pada jalur transportasi regional dan sekaligus sebagai batas koridor Jawa Tengah dengan Jawa Timur, sebagai dampaknya pertumbuhan ekonomi, aktivitas, serta pertumbuhan fisik di Sragen berkembang dengan cukup cepat. Selain hal tersebut Sragen merupakan salah satu daerah yang memiliki potensi cukup besar sebagai pusat kegiatan ekonomi, indikator pertama dalam melihat perkembangan ekonomi tersebut terlihat dari nilai investasi Sragen yang meningkat sangat signifikan,berdasarkan data Badan Koordinasi Penanaman Modal (BKPM) pada 
5 tahun terakhir Kabupaten Sragan memiliki 13 proyek dengan pendanaan asing yang bernilai sebesar US $\$ 18.260 .000$ dan 178 proyek dengan skema Penanaman Modal Dalam Negeri yang bernilai 2.95 Trilyun Rupiah. Sebagai dampaknya pertumbuhan ekonomi Sragen meningkat $6.12 \%$ secara agregat dalam kurun waktu yang sama.

Sebagaimana teori pertumbuhan jalur cepat (turnpike) yang dikemukanan oleh (Samuelson, 1952), pembangunan ekonomi akan selalu memiliki dampak negatif akibat ketidakmampuan beberapa kelompok masyarakat dalam merespon perubahan struktur dan program percepatan pembangunan, sehingga kelompok tersebut tidak terserap pada proses pembangunan yang akhirnya bermuara pada pengangguran dan mengakibatkan kemiskinan. BPS 2017 memberikan data bahwa secara agregat angka kemiskinan Sragen adalah 14,02\% lebih tinggi dibandingkan dengan prosentase kemiskinan di Jawa Tengah yang sebesar $13,01 \%$, hal ini mengindikasikan masih terjadi ketimpangan diantara penduduk Kabupten Sragen.

Pengangguran serta kemiskinan merupakan masalah urgent dalam pembangunan dengan dimensi yang semakin meluas, ukuran kemiskinan tidak lagi hanya dihitung dari sisi pendapatan melainkan juga dari standar kelayakan hidup. Perubahan standar ini menjadikan ukuran kemiskinan harus dapat mengakomodasi indikatorindikator yang menjelaskan kemampuan manusia untuk sejahtera,selain itu unsur spasial (kewilayahan) juga memiliki peran penting dalam pencapaian kesejahteraan masyarakat, usur wilayah akan berkorelasi dengan sumberdaya sektor primer yang terkandung dalamnya, wilayah dengan tingkat kesuburan tinggi, cenderung memiliki tingkat kesejahteraan yang tinggi dibandingkan dengan masyarakat yang tinggal diwilayah yang kurang subur. Oleh dasar itu perlu adanya pemetaan terhadap konsentrasi spasial penduduk terkategori miskin dalam melihat bagaimana sebaran dan kontribusi wilayah mempengaruhi tingkat kemiskinan mereka.

Keberhasilan pengentasan kemiskinan hanya dapat dilakukan secara bertahap yang dimulai dengan mengetahui sebaran atau pengelompokan wilayah masyarakat berkategori miskin, kemudian berdasarkan pengelompokan yang telah diketahui, kemudian analisis dilanjutkan dengan mendalami bagaimana kondisi dan karateristik masyarakat miskin tersebut, sehingga diketahui karakter kemiskinan perwilayah di Kabupaten Sragen.Kajian ini bertujuan mengidentifikasi pola dan sebaran masyarakat berdasarkan tingkat kemiskinan di Kabupaten Sragen, tahap ini digunakan sebagai dasar penyusunan profil dan penentuan lokasi prioritas program pengentasan kemiskinan di Sragen sebagai dasar aplikasi model yang efektif dan aplikatif dalam pengentasan kemiskinan di Kabupaten Sragen.

Ditinjau dari sumber penyebabnya, kemiskinan terbagi dalam 2 jenis kemiskinan, yaitukemiskinan kultural dan kemiskinan struktural. Kemiskinan kultural adalah kemiskinan yang mengacu pada sikap seseorang atau masyarakat yang disebabkan oleh gaya hidup, kebiasaan hidup dan budayanya. Kemiskinan kultural biasanya dicirikan oleh sikap individu atau kelompok masyarakat yang merasa tidak miskin meskipun jika diukur berdasarkan garis kemiskinan termasuk kelompok miskin. Sedangkan kemiskinan struktural adalah kemiskinan yang disebabkan oleh struktur masyarakat yang timpang, baik karena perbedaan kepemilikan, kemampuan, pendapatan dan kesempatan kerja yang tidak seimbang maupun karena distribusi pembangunan dan hasilnya yang tidak merata. Kemiskinan struktural biasanya dicirikan oleh struktur masyarakat yang timpang terutama dilihat dari ukuran-ukuran ekonomi(Lewis, 1963).

Kemiskinan memang merupakan masalah multidimensi yang mencakup berbagai aspek kehidupan. Kondisi 
kemiskinan setidaknya disebabkan oleh faktor-faktor sebagai berikut: Pertama, rendahnya taraf pendidikan dan kesehatan berdampak pada keterbatasan dalam pengembangan diri dan mobilitas. Hal ini berpengaruh terhadap daya kompetisi dalam merebut atau memasuki dunia kerja. Kedua, rendahnya derajat kesehatan dan gizi berdampak pada rendahnya daya tahan fisik, daya pikir dan selanjutnya akan mengurangi inisiatif. Ketiga, terbatasnya lapangan pekerjaan semakin memperburuk kemiskinan. Dengan bekerja setidaknya membuka kesempatan untuk mengubah nasibnya. Keempat, kondisi terisolasi (terpencil) mengakibatkan pelayanan publik seperti pendidikan, kesehatan, dan lain-lain tidak dapat menjangkaunya. Kelima, ketidakstabilan politik berdampak pada ketidakberhasilan kebijakan pro-poor. Berbagai kebijakan dan program program penanggulangan kemiskinan akan mengalami kesulitan dalam implementasi jika tidak didukung oleh kondisi politik yang stabil.

Sharp, et al (1996) dalam Mudrajat Kuncoro (2004) mengidentifikasikan sebab kemiskinan dipandang dari sisi ekonomi. Pertama, secara mikro kemiskinan muncul karena adanya ketidaksamaan pada kepemilikan sumberdaya yang menyebabkan distribusi pendapatan yang timpang. Penduduk miskin hanya memiliki sumberdaya dalam jumlah terbatas dan kualitasnya rendah. Kedua, kemiskinan muncul akibat perbedaan dalam kualitas sumberdaya manusia. Kualitas sumberdaya manusia rendah berarti produktivitasnya rendah, yang pada gilirannya upahnya rendah. Rendahnya kualitas sumberdaya manusia ini karena rendahnya pendidikan, nasib kurang beruntung, adanya diskriminasi atau karena keturunan. Ketiga, kemiskinan muncul akibat perbedaan akses dalam modal. Ketiga penyebab kemiskinan ini bermuara pada teori lingkaran setan kemiskinan (vicious circle of poverty). Teori ini ditemukan oleh Ragnar Nurkse (1953) dalam Kuncoro, 2004, yang mengatakan "a poor country is poor because it is poor" (Negara miskin itu miskin karena dia miskin). Adanya keterbelakangan, ketidaksempurnaan pasar, dan kurangnya modal menyebabkan rendahnya produktivitas. Rendahnya produktivitas mengakibatkan rendahnya pendapatan yang mereka terima. Rendahnya pendapatan akan berimplikasi pada rendahnya tabungan dan investasi. Rendahnya investasi berakibat pada keterbelakangan. Oleh karena itu, setiap usaha untuk mengurangi kemiskinan seharusnya diarahkan untuk memotong lingkaran dan perangkap kemiskinan ini (Mudrajad Kuncoro, 2004).

Ada beberapa hal yang menyebabkan terjadinya konsentrasi kemiskinan. Perbedaan kemajuan pembangunan suatu wilayah akan menimbulkan kesenjangan pendapatan, yang sekaligus akan menimbulkan perbedaan tingkat kemiskinan. Pada umumnya perkembangan ekonomi tidak terjadi secara serentak di semua sektor dan wilayah. Beberapa tumbuh dengan cepat, sedangkan beberapa sektor mengalami perkembangan yang lebih lambat.

Teori-teori pertumbuhan regional sebagian besar merupakan konsep unbalanced growth, sebagaimana yang dijelaskan oleh Hirscman bahwa pertumbuhan tidak seimbang merupakan usaha pembangunan yang dipusatkan pada beberapa sektor yang mendorong berbagai sektor pada periode berikutnya. Perroux, 1955 menyatakan bahwa pertumbuhan tidak muncul di berbagai wilayah pada waktu yang sama. Pertumbuhan terjadi di beberapa tempat yang merupakan pusat pertumbuhan dengan intensitas yang berbeda.

Konsentrasi aktivitas ekonomi akan berpengaruh terhadap perkembangan wilayah tersebut. Pembangunan suatu wilayah mungkin akan memiliki dampak yang berbeda bahkan bertentangan antar wilayah. Myrdal menyebutkan dampak yang positif sebagai (spread effects) dan negatif sebagai (backwash effects). Di beberapa tempat mungkin spread effects dan backwash effects 
memiliki kekuatan yang sama pada periode tertentu sehingga seolah-olah terjadi keseimbangan. Teori sumberdaya manusia menyebutkan bahwa penduduk di daerah miskin akan memiliki pendidikan yang lebih rendah dan lebih mendorong perbedaan spasial kemiskinan antar daerah.

\section{METODE PENELITIAN}

Metode Penelitian dilakukan melalui pendekatan kualitatif dan kuantitatif dengan kecamatan di wilayah Kabupaten Sragen sebagai unit analisis. Data kualitatif yang dihasilkan dalam kajian ini ditampilkan dalam bentuk narasi eksplorasi secara informatif dan komprehensif. Adapun data kuantitatif yang akan dihasilkan dalam penelitian ini disajikan dalam bentuk matrik numerik, tabel dan gambar kuantitatif terkait dengan trend suatu objek, dan semua data yang diperoleh dianalisis secara eksploratifkomparatif menggunakan metoda statistika serta analisis spasial dalam permodelan Sistem Informasi Geografis (SIG). Kajian ini menggunakan 2 metoda dalam pengolahan data, pertama, data diolah dengan pendekatan spasial dengan alat bantu ArcGIS 9 untuk memperoleh peta konsentrasi penduduk berkategori miskin di Kabupaten Sragen. Kedua, data diolah menggunakan pendekatan statistik untuk mendapatkan rasio tercait dengan Head Count Indeks (HCI) pada masing-masing wilayah analisis.

Analisis sebaran dan konsentrasi masyarakat miskin di Sragen dilakuan dengan metodeoptimasi Jenks, atau disebut juga Jenks Natural Breaks Classification, yaitu metode pengelompokan data yang dirancang untuk menentukan pengaturan nilai terbaik ke dalam kelas yang berbeda. Hal ini dilakukan dengan meminimalkan penyimpangan rata-rata setiap kelas dari ratarata kelas, sambil memaksimalkan penyimpangan masing-masing kelas dari cara kelompok lain. Dengan kata lain, metode ini berupaya mengurangi varians di dalam kelas dan memaksimalkan varians di antara kelaskelas yang terbangun. Adapun rumus yang digunakan dalam perhitungannya adalah sebagai berikut;

$$
S S D_{i \ldots j}=\sum_{k=i}^{j} A[k]^{2}-\frac{\left(\sum_{k=i}^{j} A[k]\right)^{2}}{j-i+1}
$$

dimana, A adalah banyaknya jumlah observasi pada sampel anlisis yang bernilai 1 sampai dengan $\mathrm{N}$, dan berada pada rentangan nilai $1 \leq \mathrm{i}<\mathrm{j}<\mathrm{N}$, sedangkan $\mathrm{i}$. j adalah ratarata kelas yang dibatasi oleh $\mathrm{i}$ dan $\mathrm{j}$. Tahapan dalam analisis ini dilakukan dalam ArcGIS untuk sekaligus mendapatkan peta konsentrasi masyarakat miskin di Kabupaten Sragen. Tahapan dalam analisis ini dijabarkan sebagai berikut; (1). Sebaran total penduduk miskin Sragen, tahapan ini dilakukan untuk mengetahui konsentrasi wilayah berdasarkan jumlah masyarakat yang terkatogori miskin berdasarkan data mikro BDT Tahun 2017. teridentifikasinya, data ini sangat diperlukan sebagai dasar analisis pola penyebarannya (difusi) yang selanjutnya akan diolah menggunakan analisis SIG untuk melihat penyebaranya dalam peta wilayah geografis.

Unit wilayah dalam penelitian ini meliputi seluruh kecamatan di Kabupaten Sragen. Sedangkan pembagian masyarakat miskin dikelompokkan dalam 4 kategori DESIL sesuai dengan metode klasifikasi Tim Nasional Percepatan Penanggulangan Kemiskinan (TNP2K). Pada Tahap kedua, data sebaran kemiskinan dikelompokkan sesuai dengan kategori DESIL pada masingmasing unit analisis, hasil analisis tahap ini digunakan untuk mengetahui sebaran wilayah kelompok kemiskinan di Kabupaten Sragen. Pada tahap terahir, akan dihitung rasio kelompok masyarakat miskin dibandingkan dengan total penduduk di wilayah tersebut untuk melihat tingkat kedalam kemiskinan berdasarkan metode Head Count Indeks.

\section{HASIL DAN PEMBAHASAN}

Kabupaten Sragen secara administratif terbagi menjadi 20 kecamatan, 12 kelurahan, dan 196 desa, secara geografis luas wilayah 
Kabupaten Sragen adalah sebesar 941,55 $\mathrm{km} 2$. Berdasarkan fungsinya sesuai dengan dokumen percepatan pembangunan koridor Jawa bagian Tengah, Sragen terkelompok dalam Sub Wilayah Pembangunan (SWP)
VIII bersama Surakarta dan daerah lain disekitarnya yang berfungsi sebagai connector sekaligus batas kegiatan administrasi Wilayah Jawa Tengah dan Jawa Timur.

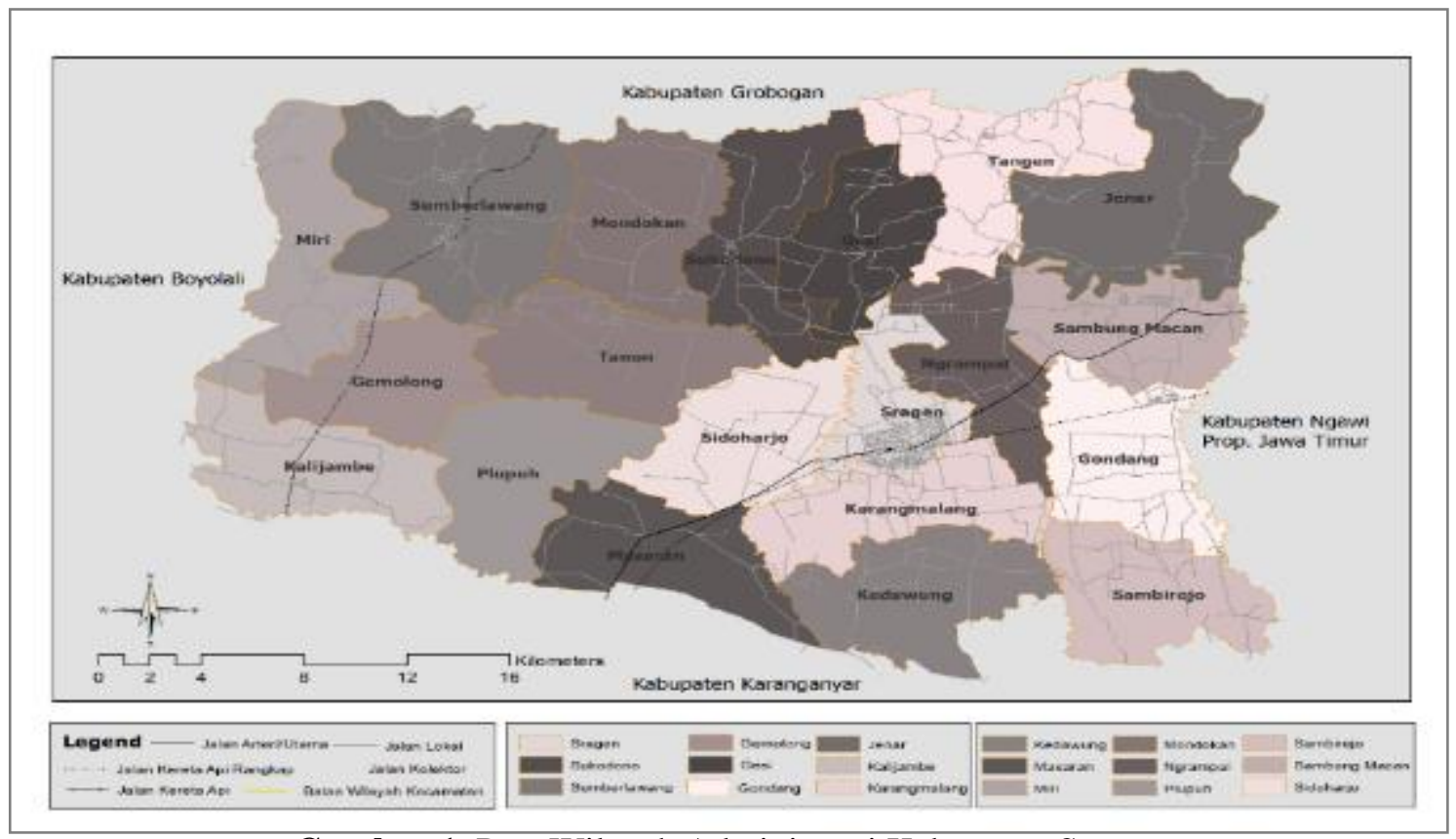

Gambar 1. Peta Wilayah Administrasi Kabupaten Sragen

Dilihat dari sisi Geografis Kabupaten Sragen berada di daerah lembah aliran Sungai Bengawan Solo yang mengalir ke arah timur. Sebagian besar merupakan dataran rendah dengan ketinggian antara 70-480 meter diatas permukaan air laut dan bagian utara merupakan daerah perbukitan sebagai bagian dari rangkaian Pegunungan Kendeng dan sebagian kecil wilayah selatan berupa perbukitan yang berada pada kaki Gunung Lawu. Kondisi tersebut menjadikan Kabupaten Sragen memiliki kontur yang berbeda-beda, namun sebagian besar bentuk kontur/relief di Sragen berupa wilayah datar dengan kemiringan lereng 0 $5 \%$ yang terletak di Kecamatan Sambungmacan, Ngrampal, Sragen, Gondang, Karangmalang, Masaran, Sidoharjo, Plupuh, Tanon, serta sebagian Kecamatan Kalijambe dan Gemolong. Jika dijumlahkan, wilayah dengan kontur datar di wilayah Sragen memiliki luas sebesar 503,37 km2. Pada kondisi kontur ini, sebagian besar peruntunkan lahan digunakan untuk pertanian sawah dan pemukiman serta wilayah industri.

Daerah dengan kontur/relief bergelombang dengan kemiringan sebesar 5 $-15 \%$ teridentifikasi di wilayah Kecamatan Jenar, Tangen, Gesi, Sukodono, Mondokan, Sumberlawang, Miri, serta sebagian Kecamatan Gemolong, Kedawung, dan Sambirejo dengan total luas sebesar 402,64 km2. Daerah dengan kemiringan lereng 15 - $25 \%$ dengan relief berbukit rendah terdapat di sebagian Kecamatan Jenar, Mondokan, dan Sambirejo yang terbentang seluas 31,21 km2. Sedangkan daerah dengan kemiringan lereng 25-45\% dengan relief berbukit hanya terdapat di sebagian Kecamatan Sambirejo dan memiliki luas sebesar 4,17 $\mathrm{km}^{2}$ dan daerah dengan kemiringan lereng $>45 \%$ dengan relief bergunung ini juga hanya terdapat kaki Gunung Lawu yang secaraadministratif berada di Kecamatan Sambirejo dan memiliki luas sebesar $0,163 \mathrm{~km} 2$. 
Tabel 1.

Luas Wilayah Berdasarkan Kemiringan Lereng diKabupaten Sragen

\begin{tabular}{clrr}
\hline \multicolumn{2}{c}{ Kemiringan Lereng } & \multicolumn{1}{c}{ Luas } \\
\cline { 1 - 3 } $\begin{array}{c}\text { Lereng } \\
\text { \% }\end{array}$ & \multicolumn{1}{c}{ Relief } & $(\mathbf{\% m})$ & \\
\hline $0-5$ & Datar & 503,37 & 53,4 \\
$5-15$ & Bergelombang & 402,64 & 42,7 \\
$15-25$ & Berbukit rendah & 31,213 & 3,32 \\
$25-45$ & Berbukit & 4,17 & 0,44 \\
$\sim \widetilde{4} 5$ & Bergunung & 0,163 & 0,02 \\
\hline & Jumlah & $\mathbf{9 4 1 , 5 5 9}$ & $\mathbf{1 0 0}$ \\
\hline
\end{tabular}

Sumber: Sragen dalam Angka, diolah

Kabupaten Sragen memiliki keragaman relief yang cukup bervariasi, mulai dari wilayah yang berkontur dataran rendah di wilayah selatan hingga wilayah dataran tinggi di bagian utara, berbedaan ini mengandung implikasi pada perbedaan jumlah sebaran penduduk, daerah dengan kontur wilayah dataran rendah pada umumnya lebih banyak menerima tekanan pertumbuhan penduduk dibandingkan dengan wilayah lain dengan kontur dataran tinggi, hal ini terjadi karena pada wilayah dataran rendah umumnya memiliki potensi yang lebih tinggi untuk dikembangkan utamanya pada sektor pertanian.

Perbedaan kontur wilayah berakibat pada perbedaan konsentrasi penduduk di Kabupaten Sragen, hasil analisis Sistem
Informasi Geografis pada Gambar 2 menunjukkan bahwa konsentrasi penduduk Sragen berada di wilayah selatan dengan tipikal kontur dataran rendah yang memiliki kemiringan antara 0-5\%. Secara administrasi wilayah Sragen dengan penduduk terbanyak terletak di Kecamatan Masaran, Sragen, Karangmalang dan Kedawung, dimana keempat wilayah ini masing-masing memiliki jumlah penduduk lebih dari 6000 jiwa, atau jika dijumlahkan, jumlah penduduk keempat wilayah ini adalah $30 \%$ dari total penduduk Sragen pada 2016. Tingginya konsentrasi penduduk pada wilayah ini dipengaruhi oleh pusat kegiatan administrasi Sragen yang terletak di Kecamatan Sragen, sehingga hinterlandnya yaitu (Masaran, Karangmalang dan Kedawung) ikut tumbuh sebagai penopang aktifitas di Sragen. Disisi lain Kecamatan Gesi adalah wilayah dengan konsentrasi penduduk terendahyang dihuni kurang dari 2000 jiwa, wilayah ini merupakan lereng dengan struktur yang didominasi oleh batuan kapur, sehingga potensi lahan untuk kegiatan pertanian kurang berkembang selain itu jauhnya jarak dengan pusat kota turut berkorelasi pada jumlah masyarakat yang tinggal di wilayah ini.

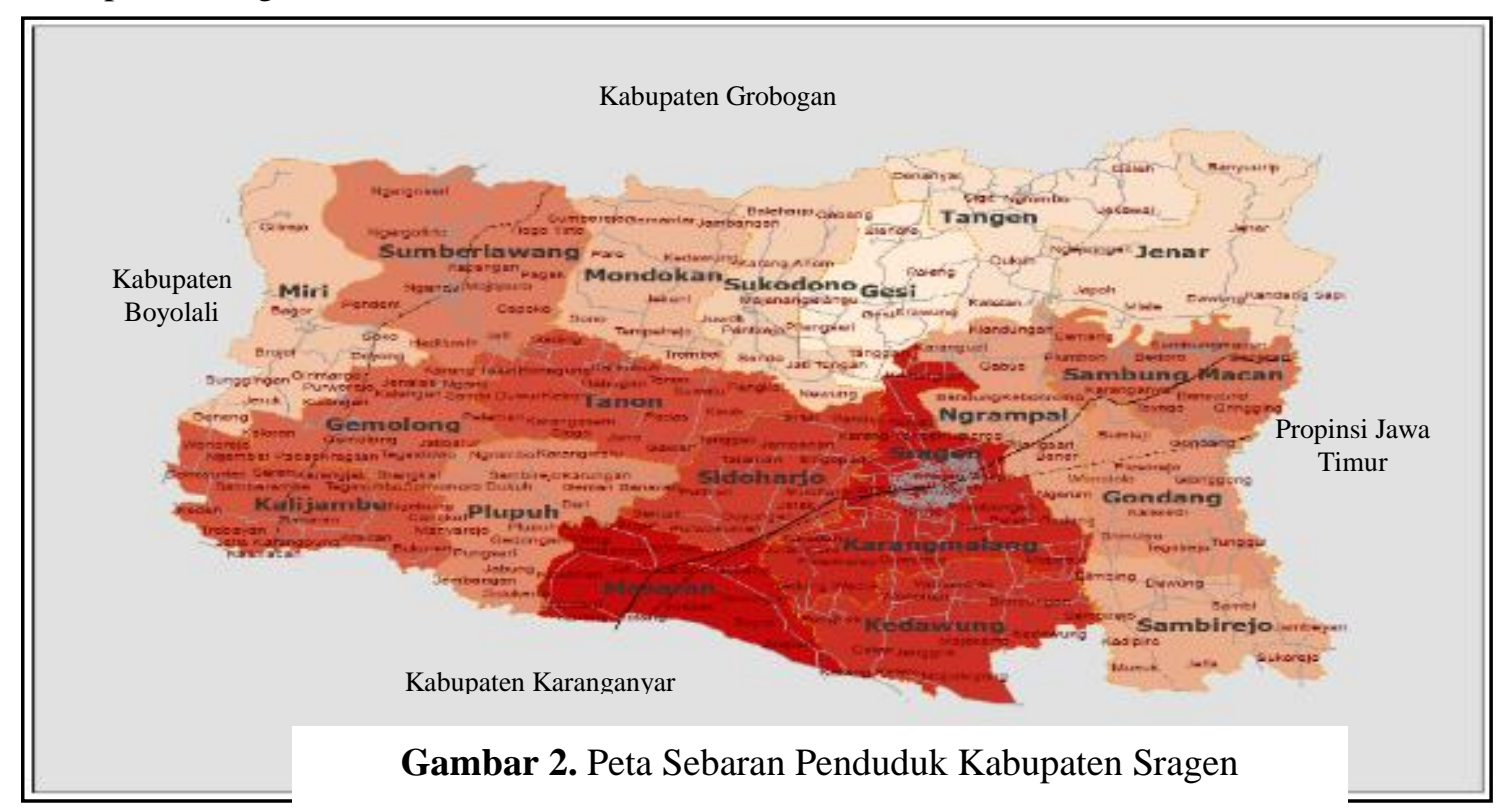




\section{Perekonomian Sragen}

Kabupaten Sragen merupakan daerah penyangga simpul ekonomi koridor VIII Pulau Jawa, bersama dengan Karanganyar, Klaten, Boyolali, dan Sukoharjo. Secara geografis Sragen terletak pada jalur transportasi regional dan sekaligus sebagai batas koridor Jawa Tengah dengan Jawa Timur, sebagai dampaknya Sragen mempunyai peran penting dalam sirkulasi dan distribusi faktor-faktor ekonomi wilayah Propinsi Jawa Tengah dan Jawa Timur. Mendasarkan pada proporsi PDRB Kabupaten Sragen, sebagaimana Grafik 1, sektor dominan dalam proporsi ekonomi Kabupaten Sragen disumbang dari 3 sektor utama, yaitu sektor industri pengolahan, perdagangan dan pertanian.

Ketiga sektor ini secara bersamasama mengendalikan perputaran ekonomi Sragen dengan sektor inti bertumpu pada sektor industri pengolahan yang bernilai $33.87 \%$ dari total perolehan PDRB Sragen. Pada pencapaian kinerja investasi, Badan Koordinasi Penanaman Modal (BKPM) menjelaskan terjadinya kenaikan yang sangat signifikan pada penyerapan investasi asing maupun dalam negeri pada kurun waktu 5 tahun, BKPM mencatat masuknya 13 proyek dengan pendanaan asing yang bernilai US \$ 18.26 Juta dan 178 proyek dengan skema PMDM yang bernilai 2.95 Trilyun Rupiah, akselerasi ini mendorong pertumbuhan ekonomi Sragen pada angka 5.72 persen secara agregat pada tahun 2016.

\section{Grafik1.}

Komposisi Produk Domestik Regional Bruto

Kabupaten Sragen 2107

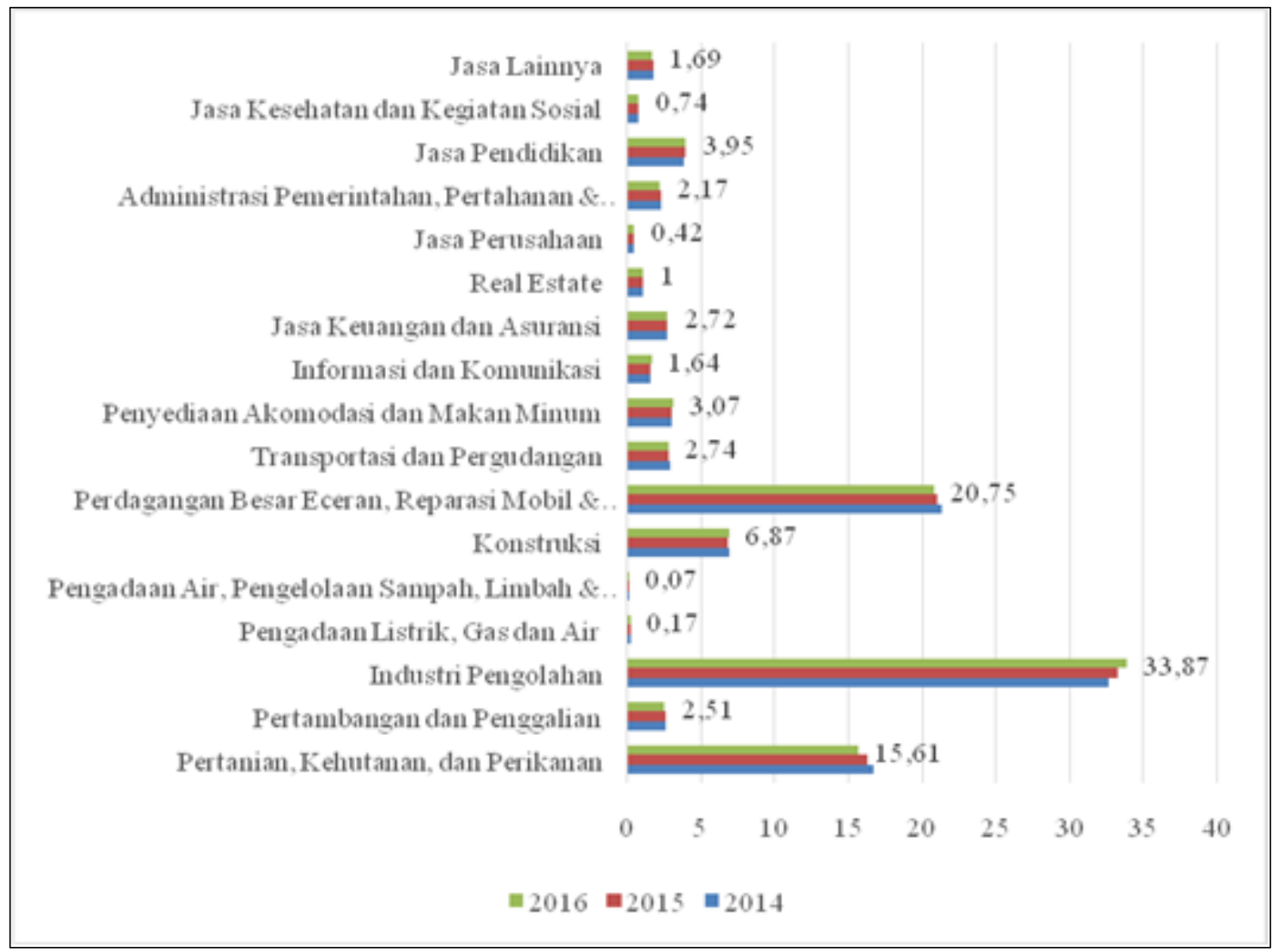

Sumber: BPS 2107,Sragen Dalam Angka 2107 
Arif, Muhammad menjelaskan bahwa dalam koridor Jawa Tengah, Kabupaten Sragen memiliki 8 sektor industri unggulan yang didominasi oleh industri kecil dan menengah dengan jenis industri berupa Industri makanan, tekstil, Pakaian Jadi, industri Kayu Barang dari Kayu dan Gabus (Tidak Termasuk Furnitur), industri Farmasi, lndustri Barang Galian Bukan, industri Furnitur, industri Reparasi dan Pemasangan Mesin dan Peralatan. Lebih lanjut dijelaskan pula bahwa sebaran industri tersebut terkonsentrasi utamanya pada Kecamatan Plupuh dan Masaran, dimana pada kedua wilyah tersebut ditemukan konjungsi spasial baik berdasarkan unit usaha maupun konsentrasi tenaga kerja pada sektor industri tekstil, sehingga dalam kesimpulannya dikatakan bahwa industri tekstil adalah industri utama Kabupaten Sragen yang mempu menyerap tenaga kerja dan membentuk wilayah sentralistik kegiatan ekonomi daerah di wilayah Sragen.

\section{Profil Kemiskinan Kabupaten Sragen}

Kabupaten Sragen merupakan satu dari 15 wilayah yang menjadi fokus pemerintah Propinsi dalam pegentasan kemiskinan dalam koridor Jawa Tengah, data yang dirilis BPS menunjukkan bahwa posisi relatif kemiskinan Sragen adalah 14.02 persen, lebih tinggi 1.02 persen dari tingkat kemiskinan relative di Propinsi Jawa Tengah dan lebih tinggi 4.6 persen jika dibandingkan dengan tingkat kemiskinan di Indonesia, hal demikian menunjukkan bahwa komposisi penduduk miskin di Sragen masih cukup tinggi dibandingkan dengan wilayah lain di Jawa Tengah maupun nasional.

Klasifikasi tingkat kesejahteraan masyarakat yang digunakan dalam kajian ini menggunakan standar yang digunakan oleh pemerintah melalui BPS dan TNP2K yang membagi kesejahteraan masyarakat dalam satuan individu dan rumah tangga pada 4 kategori DESIL, dimana Desil 1 adalah Rumah Tangga/Individu dengan kondisi kesejahteraan $10 \%$ terendah di Indonesia atau diartikan sebagai kelompok masyarakat yang sangat miskin, kategori Desil 2, adalah kelompok Rumah Tangga/Individu dengan kondisi kesejahteraan 11\%-20\% terendah di Indonesia, kategori ini disebut sebagai golongan masyarakat miskin. Desil 3 adalah kelompok masyarakat dengan tingkat kesejahteraan antara 21\%-30\% terendah, atau disebut sebagai masyarakat hampir miskin. Terakir Desil 4 dimana kelompok ini memiliki tingkat kesejahteraan yang berkisar antara $31 \%$ $40 \%$ terendah di Indonesia, disebut dalam ketegori kelompok masyarakat rentan miskin.

\section{Grafik 2}

Posisi Relatif Tingkat Kemiskinan Kabupaten/ Kota di Jawa Tengah (2017, Maret)

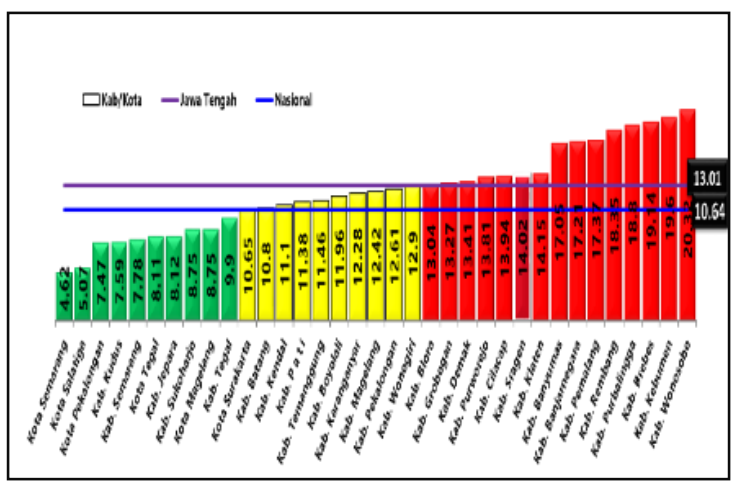

Sumber: BPS Jawa Tengah, 2017

Klasifikasi tingkat kesejahteraan masyarakat yang digunakan dalam kajian ini menggunakan standar yang digunakan oleh pemerintah melalui BPS dan TNP2K yang membagi kesejahteraan masyarakat dalam satuan individu dan rumah tangga pada 4 kategori DESIL, dimana Desil 1 adalah Rumah Tangga/Individu dengan kondisi kesejahteraan $10 \%$ terendah di Indonesia atau diartikan sebagai kelompok masyarakat yang sangat miskin, kategori Desil 2, adalah kelompok Rumah Tangga/Individu dengan kondisi 
kesejahteraan 11\%-20\% terendah di Indonesia, kategori ini disebut sebagai golongan masyarakat miskin. Desil 3 adalah kelompok masyarakat dengan tingkat kesejahteraan antara 21\%-30\% terendah, atau disebut sebagai masyarakat hampir miskin. Terakir Desil 4 dimana kelompok ini memiliki tingkat kesejahteraan yang berkisar antara 31\%$40 \%$ terendah di Indonesia, disebut dalam ketegori kelompok masyarakat rentan miskin.

\section{Klasifikasi dan Distribusi Spasial Masyarakat Miskin Sragen}

Hasil analisis dalam kajian ini menunjukkan bahwa pengelompokkan masyarakat dalam kategori $40 \%$ kesejahteraan terendah di Sragen dengan menggunakan Mikro data BDT tahun 2015 mengidentifikasi sejumlah 81.620 Kepala Rumah Tangga dan sebanyak 250.294 individu masuk dalam kategori masyarakat kurang sejahtera. Update terkini data BDT yang dilakukan pada tahun 2017, menunjukkan penambahan jumlah masyarakat miskin di Sragen sebesar 30\%, diketahui jumlah KRT meningkat menjadi
106.007 dan individu sebanyak 327.143 jiwa. Kelompok masyarakat ini sebagian besar terkonsentrasi pada wilayah utara dan barat Kabupaten Sragen sebagaimana ditunjukkan oleh Gambar 2.

Gambar 3 menunjukkan bahwa sebaran jumlah masyarakat miskin di Sragen memiliki pola yang cenderung mengelompok, konsentrasi tersebut teridentifikasi di wilayah Kecamatan Sumberlawang dengan jumlah penduduk miskin sebanyak 20719 jiwa, jika dibandingkan dengan jumlah penduduk Sumberlawang yang sebanyak 44197 jiwa, maka pada tahun 2015 proporsi penduduk miskin di Suberlawang adalah $40 \%$. Wilayah dengan jumlah penduduk miskin terbanyak kedua adalah Kecamatan Tanon, jumlah masyarakat miskin pada daerah ini teridentifikasi sebanyak 20155 jiwa atau $39 \%$ dari proporsi penduduknya. Secara spasial kedua wilayah ini berdekatan langsung, maka dapat diartikan bahwa unsur geografis memiliki impact terhadap banyaknya penduduk miskin pada kedua wilayah ini.

\section{}

Gambar 3. Peta Sebaran Penduduk Miskin Kabupaten Sragen

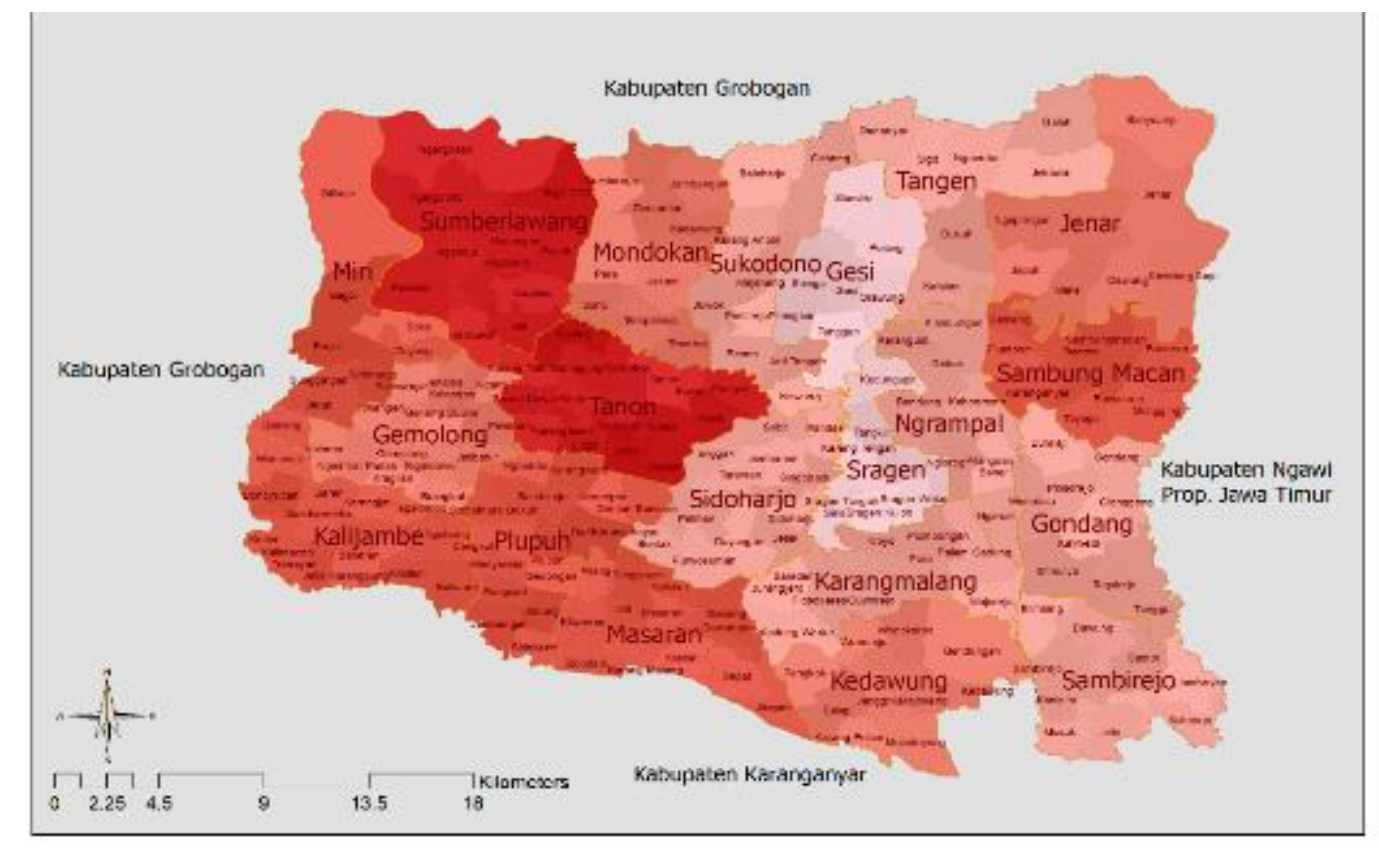

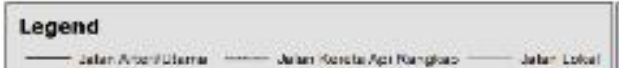

Koneentrasi Masyarakat Miskin Kabupoten Sragen

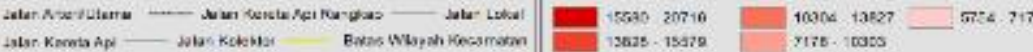

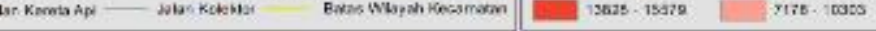




\section{Distribusi Spasial Masyarakat Miskin Kabupaten Sragen Kategori DESIL 1 \\ Kategori masyarakat miskin}

kelompok Desil 1, disebut sebagai kelompok paling miskin, kelompok ini secara absolut memiliki pendapatan di bawah garis kemiskinan yang pada umumnya tidak memiliki sumber pendapatan sama sekali serta tidak memiliki akses terhadap berbagai pelayanan sosial. Analisis menunjukkan ciri bahwa Desil 1 didominasi oleh penduduk berusia lanjut dan masyarakat yang tergantung pada sektor pertanian. Kelompok ini teridentifikasi berjumlah 11.590 KRT dan 44.549 jiwa, dan sebagian besar terdistribusi di bagian utara Sragen. Sebagaimana dijelaskan pada bagian gambaran umum geografis, wilayah utara Kabupaten Sragen merupakan wilayah dengan kontur lereng dan perbukitan yang cukup tinggi yaitu sebesar 25-45\%, merupakan pegunungan kapur, dan cenderung memiliki potensi lahan yang rendah

Secara statistik distribusi penduduk sangat miskin Kabupaten Sragen dapat dilihat dalam Grafik 4.3, dalam grafik tersebut diketahui bahwa wilayah dengan konsentrasi penduduk sangat miskin yang paling banyak (diatas 5000 jiwa) secara berturut-turut adalah Mondokan, Tangen dan Jenar, kemudian diikuti oleh Kecamatan Sumberlawang. Wilayah dengan jumlah penduduk sangat miskin yang paling rendah berturut - turut adalah Kecamatan Sragen, Sidoharjo dan Masaran. Ketiga wilayah ini merupakan pusat aktifitas ekonomi dan pemerintahan, sehingga warga miskin diketiga wilayah ini telah banyak mendapatkan manfaat dari program penanganan kemiskinan dan bantuan dari pemerintah maupun masyarakat sekitar.

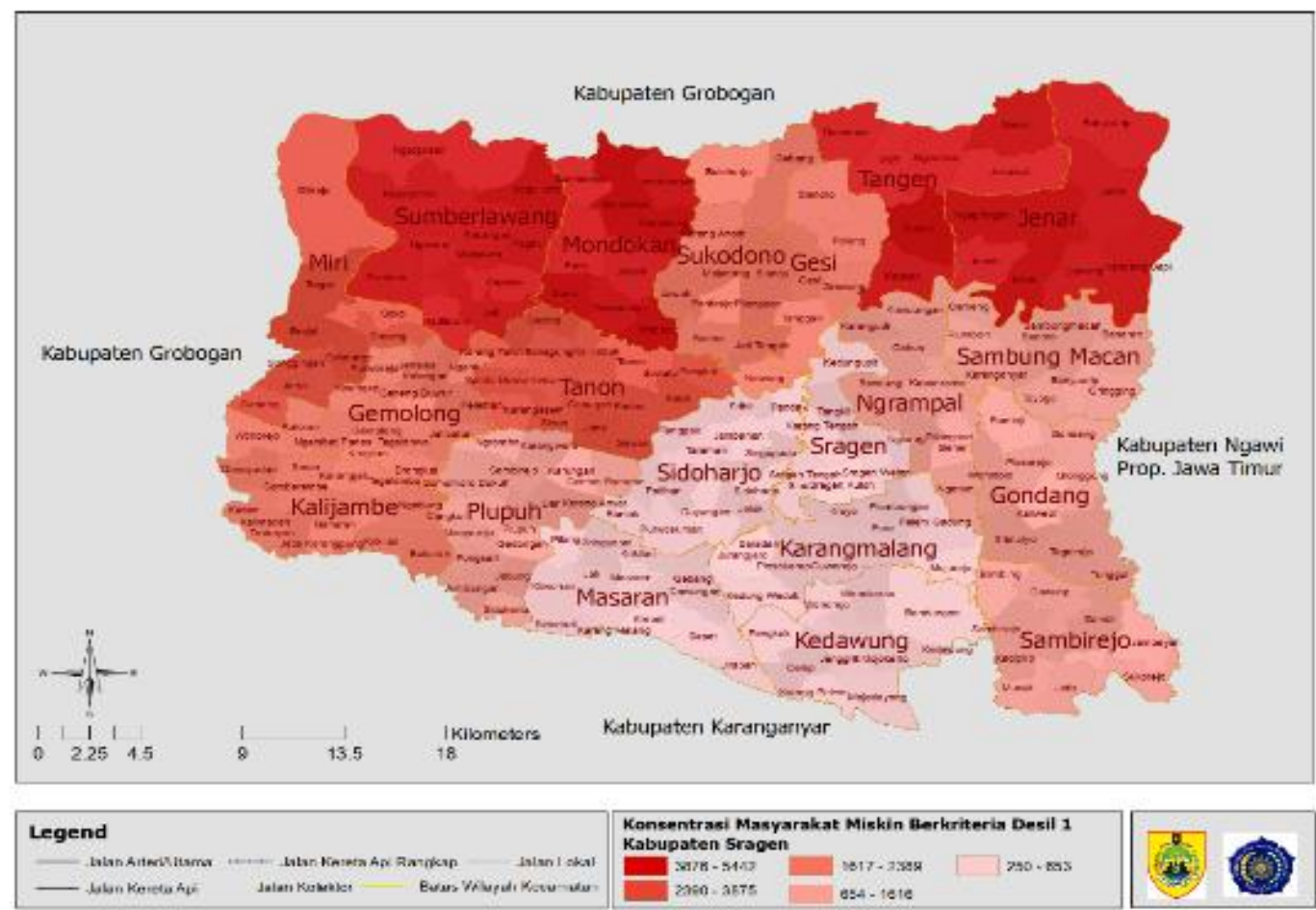

Gambar 4. Peta Sebaran Penduduk Miskin Kabupaten Sragen Kategori Desil 1 


\section{Distribusi Spasial Masyarakat Berkategori DESIL 2}

Desil 2 merupakan pengelompokan masyarakat miskin dengan tingkat kesejahteraan antara $11 \%$ - 20\% terendah. Kelompok ini memiliki pendapatan di bawah garis kemiskinan namun secara relatif memiliki akses terhadap pelayanan sosial dasar. Hasil pengolahan data menunjukkan bahwa kelompok ini memiliki kecenderungan jumlah yang tinggi, tercatat sebanyak 25.518 kepala rumah tangga serta 80.923 penduduk. Secara spasial sebagaimana gambar 4.6, konsentrasi jumlah masyarakat miskin pada Desil 2 terdapat di wilayah Sumberlawang dan Tanon. Kedua wilayah ini memiliki ciri fisik geografis yang hampir mirip dan sebagian besar masyarakatnya terikat dengan pertanian sebagai mata pencaharian walaupun pertanian cukup maju di wilayah ini, bahkan beberapa petani telah mengupayakan pertanian organic, namun supply irigasi masih terbatas, sehingga mayarakat petani sangat rentan terhadap perubahan iklim, jika musim hujan pertanian wilayah ini cukup dapat memberikan manfaat besar bagi masyarakat, namun ketika kemarau panjang terjadi, banyak lahan menjadi tidak produktif yang berakibat pada kegagalan panen dan bermuara pada meningkatnya kemiskinanpola kemiskinan seperti ini oleh Sumitro Djoyohadikusumo disebutkan sebagai seasonal poverty yang jumlahnya dinamis mengikuti perubahan kondisi alam atau ekonomi.Grafik 4.4 menunjukkan secara statistik ditribusi penduduk kategori Desil 2 Sragen, wilayah dengan jumlah penduduk berkategori Desil 2 terbanyak adalah wilayah Tanon dengan total Penduduk sebanyak 7.476 jiwa, kemudian diikuti oleh wilayah Sumberlawang sejumlah 7.269, pada urutan ketiga adalah Kecamatan Plupuh yang memiliki jumlah penduduk miskin sebanyak 5.360, dan diikuti oleh Kecamatan Sambungmacan dan Kalijambe. Sedangkan wilayah dengan jumlah penduduk miskin paling sedikit adalah wilayah Kecamatan Sragen dan Sidoharjo. Kondisi kemiskinan pada kategori sangat penting dan perlu menjadi fokus pengentasan, berdasarkan data, diketahui bahwa kategori Desil 2 ini sebagian besar merupakan penduduk usia produktif.

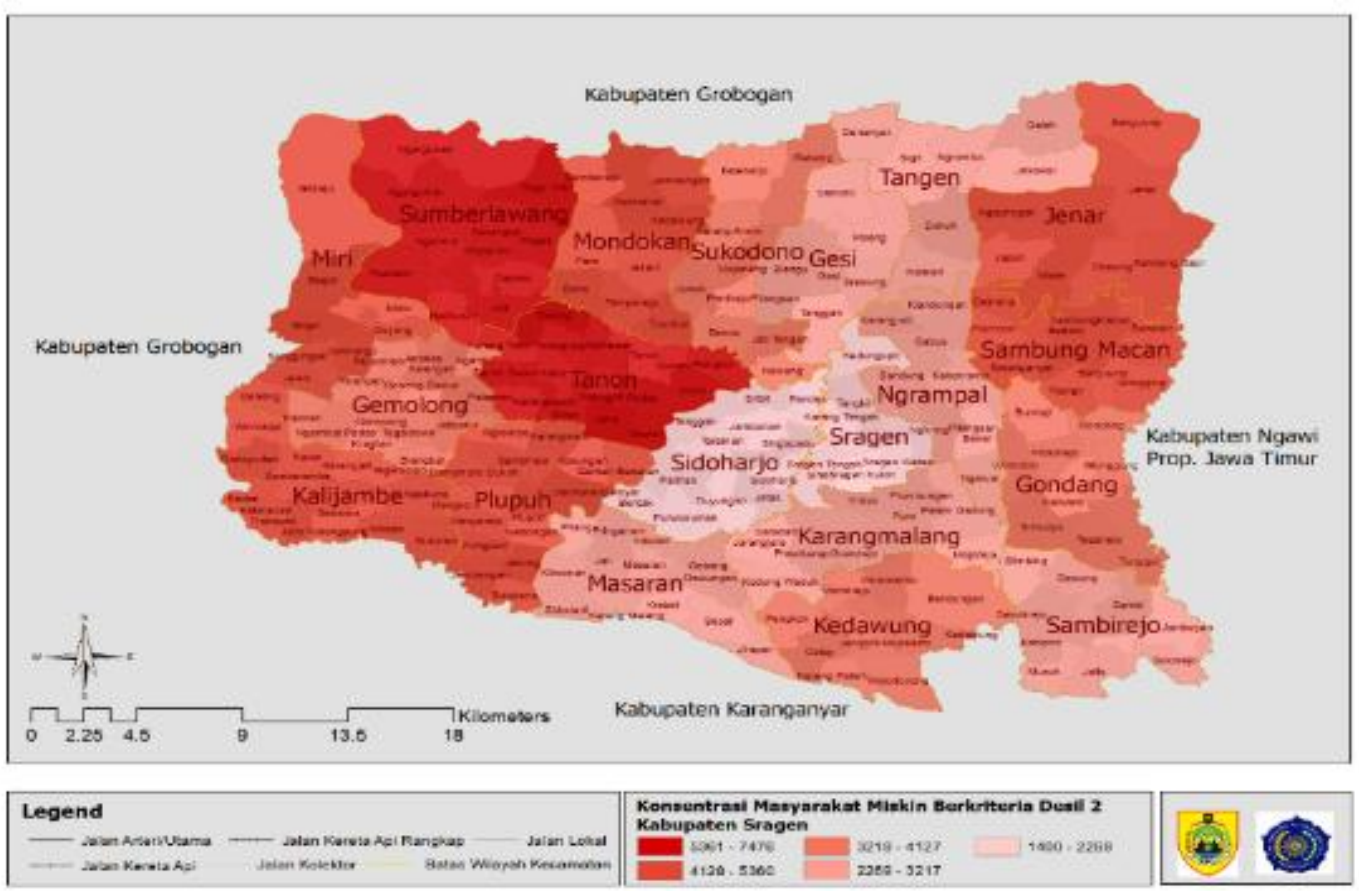

Gambar 5. Peta Sebaran Penduduk Miskin Kabupaten Sragen Kategori Desil 2 


\section{Distribusi Spasial Masyarakat Berkategori DESIL 3 Sragen}

Sesuai pengertiannya, tingkat kemiskinan pada kelompok Desil 3 adalah kelompok masyarakat yang tingkat kesejahteraamya antara $21 \%$ hingga $30 \%$ se-Indonesia atau disebut kelompok masyarakat hampir miskin. Kelompok ini dicirikan dengan tingkat pendapatan yang sedikit diatas garis kemiskinan, maka dapat dikatakan kelompok ini sangat rentan terhadap shock pada struktur ekonomi dan sosial, pada kelompok ini total penduduk yang terklasifikasi adalah sebanyak 28,362 Kepala RT dan 80,288 jiwa dan terkonsentrasi di bagian barat Sragen yang berbatasan dengan Kabupaten Boyolali. Analisis distribusi spasial menunjukkan bahwa wilayah dengan konsentrasi penduduk desil 3 tertinggi terletak di Sumberlawang, Tanon dan Masaran, kemudian diikuti oleh Kecamatan Plupuh, Kalijambe dan Sambung Macan.Secara statistik komposisi/sebaran jumlah penduduk hampir miskin di Sragen didominasi oleh Kecamatan Masaran dengan jumlah penduduk hampir miskin sebanyak 6.508 jiwa, kemudian diikuti oleh Tanon dengan jumlah penduduk sebanyak 6.184, dan Sumberlawang dengan jumlah penduduk hampir miskin sebanyak 5.941. Disisi lain daerah dengan jumlah penduduk hampir miskin yang terendah berada di derah Tangen dan Gesi, dimana keduanya memiliki jumlah penduduk hampir miskin kurang dari 2000 jiwa.

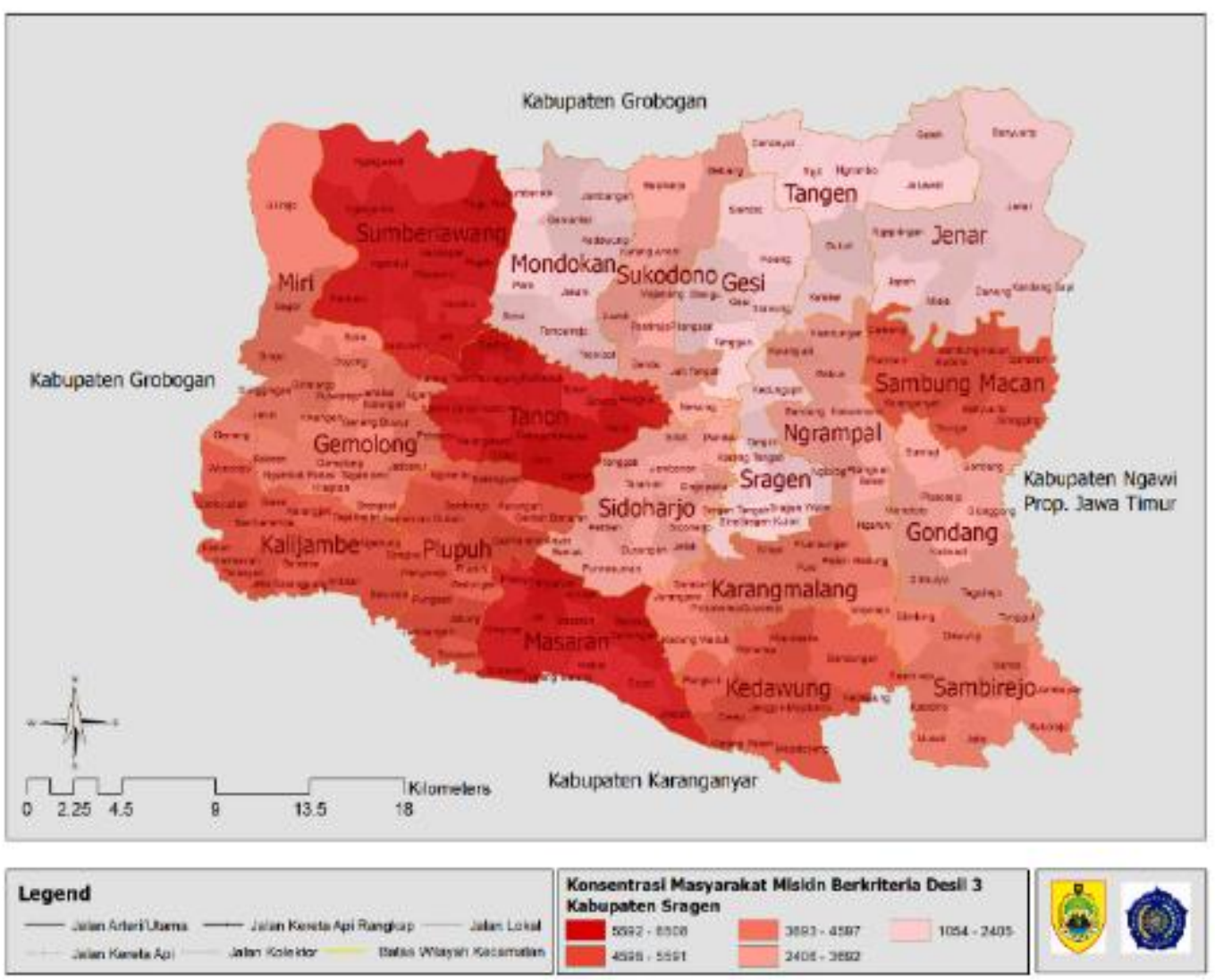

Gambar 6. Peta Sebaran Penduduk Miskin Kabupaten Sragen Kategori Desil 2 


\section{Distribusi Spasial Masyarakat} Berkategori DESIL 4 Sragen

Desil 4 merupakan kelompok masyarakat rentan (vunerable group). Kelompok ini dapat dikategorikan bebas dari kemiskinan, karena memiliki kehidupan yang relatif lebih baik dibandingkan dengan kelompok sangat miskin maupun miskin. Namun sebenarnya kelompok ini masuk dalam kategori yang sering disebut "near poor" (mendekati miskin) dimana kelompok ini masih rentan terhadap berbagai perubahan sosial di sekitarnya. Mereka seringkali berpindah dari status "rentan" menjadi "hampir miskin" dan bahkan "miskin" bila terjadi krisis ekonomi dan tidak mendapat pertolongan sosial. Hasil analisis Sistem Informasi Geografis menunjukkan terjadinya pemusatan penduduk kategori desil 4 pada wilayah kecamatan Masaran, sedangkan wilayah lain cenderung menyebar dengan pola yang merata di hampir seluruh wilayah Sragen. Secara statistic jumlah penduduk rentan miskin dijelaskan dalam Grafik 4.6, dimana diketahui jumlah penduduk rentan miskin di Masaran berjumlah 4.263 jiwa. Sedangkan wilayah lain dengan jumlah penduduk rentan miskin yang cukup banyak terdapat di wilayah Gemolong dan Kalijambe yang masing-masing memiliki jumlah sebanyak 3.066 dan 3.022 jiwa.
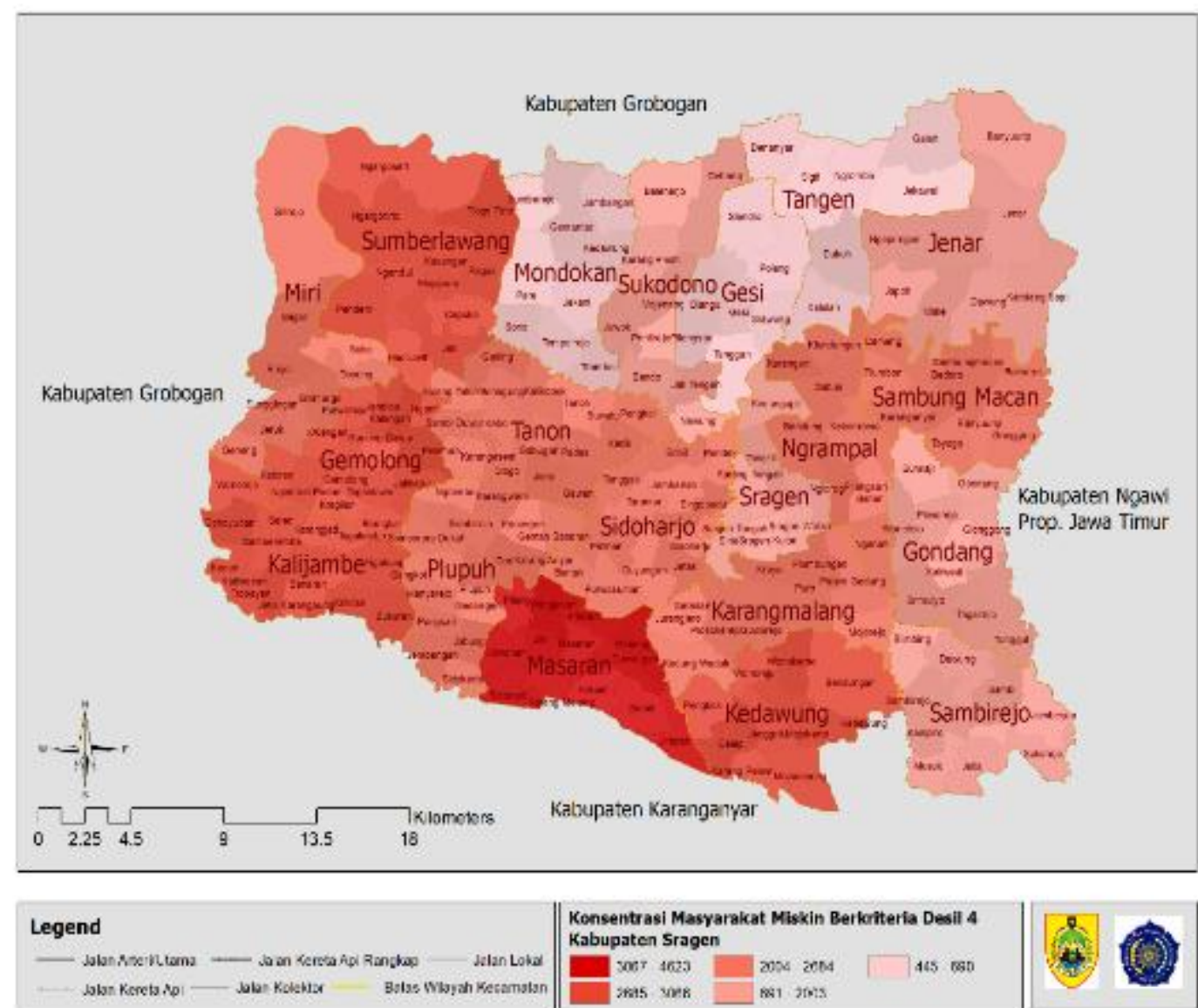

Gambar 7. Peta Sebaran Penduduk Miskin Kabupaten Sragen Kategori Desil 4

Rasio Penduduk Miskin Kabupaten Sragen

Rasio jumlah penduduk miskin terhadap komposisi jumlah penduduk atau disebut head count index (HCI) adalah rasio yang digunakan dalam penentuan postur kependudukan wilayah, tingginya rasio ini berdampak pada kurang efektifnya program 
pembangunan yang berimplikasi pada rendahnya pertumbuhan dan akselerasi daerah. Pemerintah harus membayar mahal dengan mengadakan program pengentasan kemiskinan yang tentu akan membebani anggaran daerah yang seharusnya digunakan untuk stimulus pembangunan. Pada Grafik 3 ditunjukkan hasil perhitungan $\mathrm{HCI}$, diketahui bahwa rasio penduduk sangat miskin (Desil 1) tertinggi diketahui terjadi pada daerah Tangen dan Jenar, HCI Tangen diketahui bernilai 20\%, dimana hal ini menunjukkan bahwa sebanyak 20\% warga Tangen adalah penduduk sangat miskin. Hampir sama dengan Tangen, Kecamatan Jenar juga memiliki proporsi yang tinggi pada kategori Desil 1 yaitu sebanyak 19\%.

Kategori Desil 2, wilayah dengan rasio tertinggi teridentifikasi di Kecamatan Jenar dan Sumberlawang, pada Kecamatan Jenar proporsi penduduk miskin (Desil 2) bernilai $17 \%$ dan $16 \%$ diKecamatan Sumberlawang. Jika dihubungkan dengan Grafik 4.4 maka diketahui bahwa Kecamatan Sumberlawang merupakan salah satu wilayah dengan jumlah dan rasio penduduk miskin terbanyak di Sragen.

Pada kategori penduduk hampir miskin (Desil 3) hasil analisis mengidentifikasi Kecamatan Sumberlawang, Miri dan Plupuh sebagai wilayah dengan penduduk hampir miskin terbanyak di Sragen dengan komposisi sebanyak $13 \%$ dari total penduduknya. Sedangkan pada desil 4, penduduk rentan miskin terbanyak terdapat di Kecamatan Miri dan Nrampal, dengan nilai masingmasing $8 \%$ dan $7 \%$. Secara agregat di tingkat kabupaten, wilayah yang yang mengandung komposisi penduduk sangat miskin, miskin, hampir miskin dan rentan dapat diurukan sebagai berikut; 1 Kecamatan Jenar, proporsi jumlah penduduk kurang sejahtera total di kecamatan ini mencapai $50 \%$ dari total seluruh penduduknya. Hal ini mengindikasikan bahwa Jenar merupakan Kecamatan dengan tingkat kemiskinan yang paling parah di Kabupaten Sragen. 2 Kecamatan Sumberlawang, di wilayah ini komposisi total penduduk miskinnya adalah sebanyak $47 \%$ dan ketiga adalah Kecamatan Miri dengan proporsi total penduduk miskin sejumlah $46 \%$. Jika dicermati dengan lebih mendalam ketiga wilayah ini secara spasial terletak di bagian utara Sragen dan berbatasan langsung dengan Kabupaten Grobogan.

Grafik 3

Rasio Penduduk Miskin Kabupaten Sragen Berasarkan Kategori Desil

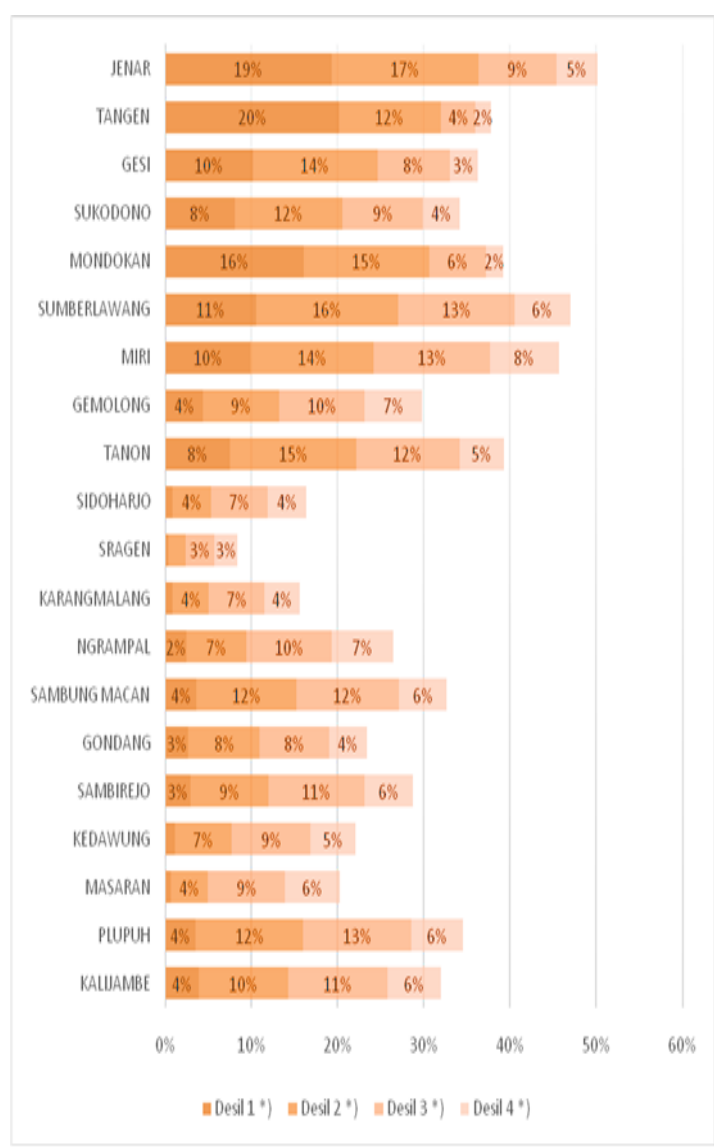

Sumber: Mikro Data BDT 2017, TNP2K 


\section{SIMPULAN}

Kajian ini menunjukkan bahwa pengelompokkan masyarakat terkategori miskin memiliki pola yang cenderung terkonsentrasi di wilayah utara dan barat Kabupaten Sragen, wilayah ini diketahui memiliki kemampuan lahan yang cukup rendah dalam menghasikan produksi pertanian karena terletak pada wilayah dengan kontur perbukitan. Jika dirinci berdasarkan kriteria kemiskinan, masyarakat yang tergolong pada kelompok Desil 1 (sangat miskin) diketahui bahwa wilayah dengan konsentrasi penduduk sangat miskin yang paling banyak (diatas 5000 jiwa) secara berturut-turut adalah Mondokan, Tangen dan Jenar, kemudian diikuti oleh Kecamatan Sumberlawang. Sedangkan pada ketegori Desil 2 (miskin) terkonsentrasi di Sumberlawang dan Tanon. Pada kategori Desil 3 (hampir miskin) terdapat di wilayah Sumberlawang, Tanon dan Masaran, kemudian diikuti oleh Kecamatan Plupuh, Kalijambe dan Sambung Macan. Sedangkan pada Desil 4 (rentan miskin) hanya terkonsentrasi di wilayah Masaran.

Hasil analisis juga mengkonfirmasi bahwa peran wilayah (lokasi) yang ditunjukkan oleh tingkat kemampuan lahan memiliki pengaruh dalam terjadinya konsentrasi kemiskinan di Kabupaten Sragen.

\section{DAFTAR PUSTAKA}

Arif, Muhammad; Utomo, Yuni Prihadi, 2016. Konsentrasi Spasial Industri-Industri Unggulan Kota Surakarta, The 3rd University Research Coloquium, Colloquium LPPM PTM/PTA Se Jawa Tengah dan Yogyakarta.Universitas Muhammadiyah Semarang.

Arif, Muhammad; Damayanti, Novita. 2018. Identifikasi Konsentrasi Spasial Industri Kecil dan Menengah Kabupaten Sragen. The 8th University Research Coloquium, Colloquium LPPM PTM/PTA Se Jawa Tengah dan Yogyakarta. Universitas Muhammadiyah Purwokerto.

Badan Pusat Statistik Jakarta Pusat (BPS). Statistik Indonesia Tahun 2017. Jakarta Pusat : Badan Pusat Statistik

BPS Kabupaten Sragen. (2017). Sragen dalam Angka 2016

BPS Provinsi Jawa Tengah. (2017). Jawa Tengah dalam Angka 2016

Cahyat, A. 2004. Bagaimana kemiskinan diukur? Beberapa model penghitungan kemiskinan di Indonesia. Poverty \& Decentralization Project CIFOR (Center for International Forestry Research) - BMZ (Bundesministerium für Wirtschaftliche Zusammenarbeit und Entwicklung). November 2004:2

Deny Ferdyansyah Dan Eko B. Santoso.2013.Pola Spasial Kegiatan Industri Unggulan Di Propinsi Jawa Timur (Studi Kasus: Subsektor Industri Tekstil, Barang Kulit, Dan Alas Kaki). Tugas Akhir. Program Studi Perencanaan Wilayah Dan Kota. Fakultas Teknik Sipil Dan Perencanaan.Institut Teknologi Sepuluh Nopember .

Fujita, M., Krugman, P., And Venables, A.J. 1999. The Spatial Economy : Cities, Regions, And International Trade. Cambrige And London : The Mit Press

Jhingan, M.L. 2000. Ekonomi Pembangunan dan Perencanaan. Jakarta, PT. Raja Grafindo Persada

Kuncoro, M, 2002. Analisis Spasial Dan Regional, Studi Aglomerasi Dan Kluster Industri Indonesia., Upp Amp Ykpn. Yogyakarta.

Kuncoro, Mudrajat. 2004. Otonomi dan Pembangunan Daerah. Jakarta, Erlangga 
LPEM UI.Teknik Dan Metode-Metode Analisis Daerah, (2003)

Perroux, F. 1955. Note Sur la Notion de Pole de Croissance. Economique Appliquee. Press Universitives de France, France

Samuelson, Paul A. 1955. Economic, McGraw-Hill Book Company, USA

Tim Nasional Percepatan Penanggulangan Kemiskinan, 2015, Basis Data Terpadu Kabupaten Sragen, TNP2K. Jakarta

Tim Nasional Percepatan Penanggulangan Kemiskinan, 2018, Basis Data Terpadu Kabupaten Sragen, TNP2K. Jakarta

Todaro, M. 1997. Pembangunan Ekonomi di Dunia Ketiga. Terj.dari Economic Development in The Third World Fourth Edition, oleh Ir. Burhanuddin Abdulla, M.A. Penerbit Erlangga. Jakarta. (378 hlm). 